\title{
The Business To Business Marketing Strategies For The Package Delivery Service Companies To Increase The Volume Of Delivery
}

\author{
Yuary Farradia ${ }^{1}$, Khaeruman $^{2 *}$, Fatari ${ }^{3}$, Ismunandar ${ }^{4}$ \\ ${ }^{1}$ Universiti Malaysia Terengganu, Malaysia \\ ${ }^{2,3}$ Bina Bangsa University, Indonesia \\ ${ }^{4}$ BIMA College of Economics, Indonesia \\ ${ }^{*}$ Corresponding author: \\ Email: khaeruman.oce@gmail.com
}

\begin{abstract}
.
In this study, the researchers used descriptive qualitative research methods with case study research on the object of research using observation, interviews, and documentation methods, data analysis techniques using SWOT analysis techniques (strengths, weaknesses, opportunities, threats) combined with IE Matrix to determine the position company. The results showed that the company uses a special tariff strategy and effective communication with customers. The IE Matrix analysis shows the company's position at a growth rate through horizontal integration, meaning that the company has the opportunity to expand the market, improve facilities, or merge with other companies in the same industry. From the results of the SWOT analysis, alternative strategies are obtained, namely: a) increasing the company's competitiveness and, b) competitive pricing policies with competitors that are adjusted to market prices.
\end{abstract}

Keywords: Marketing Strategy, Bussiness to Bussiness, Marketing Mix

\section{INTRODUCTION}

The current global crisis forces the company's management to be more responsive to such rapid changes in the environment. There seems to be a need for professionalism. Company control can no longer be carried out based on intuition or experience alone, but knowledge is another important factor that needs to be integrated. So in a recession, like we are dealing with right now, the task of management in controlling the company becomes even more difficult.Marketing business to business is marketing products or services between the company or inter-agency business with the characteristics of the marketing of goods or services in large numbers, and usually at a special price, because purchases are made in large quantities with the aim of resale.The selection of a package delivery service company is the object of research because it is a company is either a delivery company or a growing delivery expedition, along with the development of the business world which often uses expedition services in terms of distributing its services.Segmentation of the company is the industries of food and beverage, garment, furniture, cigarettes, and souvenirs industry, according to the marketing area.

With the development of the company, then it requires the company to develop marketing strategies business to business under the right to pay attention to the sector of internal and external which is owned by the company to win the market to package delivery because the market share of this company is exportoriented businesses from one region to another.Competitive conditions in the business world are very competitive shipping costs companies formulate a marketing strategy that is effective and efficient to win the market business to business. This is related to the marketing strategy for Seeing that the target market is the business world, it is necessary to have an analysis of internal and external environmental conditions. Based on the description above, the researcher stands to reason if the authors conducted the study by taking the title, namely: "The business to business marketing strategies for the package delivery service companies to increase the volume of delivery". Based on the above phenomenon, the formulation of the problem in this study are:1). How marketing strategy business-to-business service business parcel delivery company? 2). How the positive implications for marketing strategies business to business made by the Company to increase the volume of shipments? 


\section{Strategy}

According to Handoko (2007:86) strategy is a general program to achieve organizational goals in carrying out the mission. Strategy as a program to determine and achieve organizational goals and implement its mission. Kotler (2005:69) argues that strategy is a state-of-the-art, broad, and integrated plan that links the advantages of a company's strategy with environmental challenges and which is designed to ensure that the main objectives of the company can be achieved through proper implementation by the organization.From the definition of strategy, it is a unified, comprehensive, and integrated plan that links the advantages of the company's strategy by considering the conditions in the company's changing environment, both internal and external, which ultimately can achieve the main goals that have been set.

\section{Marketing}

Marketing is a social process by which individuals and groups obtain needs and wants by creating, offering and exchanging things of value with one another. According to Kotler (1997:8) marketing is a social and managerial process in which individuals and groups obtain their needs and desires in creating, offering, and exchanging something of value to one another.Meanwhile, according to Swastha and Basu (1991:78) marketing is a whole system of business activities aimed to plan, establish, promote and distribute the existing needs of the buyer. Marketing is an overall system of business activities aimed at planning, pricing, promoting, and distributing goods and services that satisfy the needs of both existing and potential buyers.

Mushlich (2004:93) says that the marketing process can be done in several stages including:

1. There are needs and desires in society

2. There is purchasing power in society

3. There is a desire for a decision to make a purchase transaction in the community.

While in his Chandra (2002:218) says that the marketing process that includes sales and distribution include:

1. Determine sales and distribution objectives to determine the company's marketing strategy

2. Identify the most appropriate appeal of sales to use in achieving goals.

3. Determine and assign human and financial resources needed for sales and distribution programs.

4. Evaluate program performance to adjust the program as needed.

\section{Marketing Strategy and Benefits}

A marketing strategy is a set of guidelines and policies that are used effectively to match the marketing program (product, price, promotion, and distribution) with the target market opportunities of the business. In simpler language, a marketing strategy shows how marketing goals can be achieved.The benefits of a Marketing Strategy include: 1) Helping to provide clear company goals, objectives, and future directions for all the employees. 2) Provide clear and directed guidelines for companies in anticipating threats and taking advantage of existing opportunities properly. 3) Provide guidelines for utilizing the company's strengths to win the competition and anticipate any existing weaknesses. 4) Companies that implement strategies are more likely to succeed than companies that do not implement them.

\section{Definition of Marketing Mix}

Decisions in marketing can be grouped into four strategies, namely product strategy, pricing strategy, distribution, and promotion strategy. The combination of these four strategies is the marketing mix.According Swastha and Irawan (2003:14) marketing mix is a series of marketing variables (product, price, distribution channels, and promotion) of control used by companies to produce the desired response companies from the target market.Meanwhile, Lamb (1998:158) explains that the marketing mix refers to the alloy product strategy, promotion, distribution, and pricing that are uniquely designed to produce mutually satisfying exchanges with the intended market.From the standpoint of the marketing mix could be drawn to the conclusion that the baffling of the marketing mix is a combination of four variables: product, price, distribution, and promotion channels are combined to generate a response to something 
from consumers that is offered by the company.

\section{METHOD}

\section{Research Types and Approach}

This research uses qualitative methods with the type of case study research. According to Bog Tylor in Moelong (2002) explained that, qualitative research is a research procedure that produces descriptive data in the form of written or spoken words from people and observed behavior.Based on the description, it can be found that this descriptive research seeks to describe the object of research based on data and facts and tries to connect events or research objects as well as analyze them based on concepts that have been developed previously to facilitate researchers in solving problems.

\section{Data Sources and Types}

A data source according to Arikunto (2004: 107) is the subject of the data obtained. Furthermore, it is said that broadly speaking, there are three types of data sources which are usually abbreviated as 3P, namely:

1. People: where the researcher asks about the variables to be studied.

2. Paper: documents, archives, guidelines for decision letters, and so on where researchers read and learn something related to their research data.

3. Place: laboratory room (which contains equipment), classroom workshop, and so on where an activity related to research takes place.

\section{Data collection technique}

To collect data and information needed in this study, the researchers used three methods in data collection, namely: Observation, Interview, and Documentation,

\section{Data analysis technique}

1. Internal-External Analysis (IE Matrix) $\rightarrow$ This internal and external matrix was developed from the General Electric model (GE-Model). The parameters used include the parameters of the company's internal strength and external influences faced. (Rangkuti, 2005: 42).

2. SWOT analysis (strength, weakness, opportunity, threats) SWOT analysis is a systematic identification of factors to formulate corporate strategy. (Rangkuti, 2002:18).

\section{RESULTS AND DISCUSSION \\ Research Result Data Exposure}

The shape of this company is a limited liability company with the main business areas in the services sector expedition or delivery of goods. The company is managed by professionals who have the skills and commitment in the field of cargo, expedition, and forwarding. With such human resources, the guarantee of the services provided by the Company will be able to meet the standards set by consumers as partners or work partners. The company has human resources who can manage the business with full responsibility and professionalism that provide maximum service to consumers. This is related to the vision and mission of the company which is the operational basis.

1. Analysis of the company's internal and external environmental factors

Internal factors are obtained by utilizing all the results of functional analysis which includes analysis of marketing, finance, operations, human resources, or personnel. External factors are obtained by analyzing economic, socio-cultural, political, technological, and competitive conditions

a. Internal Environmental Factors

1) Marketing $\rightarrow$ Marketing activities business to business in the delivery company Company aligns the needs and desires of customers, the emergence of new competitors, and the rapid development of communications technology, it becomes a tough job to win the competition to increase sales turnover. In this case, the company has determined and implemented a special tariff strategy in the face of tariff war competition. On the other side, the active role of agents and sub-agents as an effective distribution channel needs to be maximized, because agents play a major role in increasing sales volume. Companies must understand customers and be able to 
see market conditions and competitors to stay afloat in the competition so as not to be abandoned by customers and also not to lose customer trust.

2) Operational $\rightarrow$ Implementation of the company's operations can be divided into three parts: the sales force, reservations, station. The salesforce plays an important role in the success of sales, the three operational parts also play a role in bringing in customers. The employees in this section do a good job in serving customers.

3) Finance $\rightarrow$ Finance is a vital issue for companies. Companies must be appropriate to allocate the funds, and the use of funds, to make the management thinking in the use of production costs to maintain a Break-Even Point (BEP), the company must reduce costs to be issued.

b. External Environmental Factors

These External Environmental Factors include economic, social-cultural, demographic, political, technological, and competitive conditions.

1) Economic Condition $\rightarrow$ Economic conditions play a very important role in the Company's activities, namely the increase in fuel oil and followed by a decrease in fuel oil at the national level, causing uncertainty in measuring the costs that must be spent on operations, so the company management must review several cost plans that have been set.

2) Social-cultural $\rightarrow$ The higher the community activity, the higher the need for delivery, as well as the rapid development of science and the development of information, making more choices of shipping products for consumers, this change is an opportunity for shipping service companies in this case the company to be more focused and professional in terms of service so that there is differentiation with other shipping service companies.

3) Demographics $\rightarrow$ The increasing number of new industries is a potential market, this will support the development of the shipping industry due to increased purchasing power.

4) Politics and Law $\rightarrow$ Political conditions that affect the company are during the legislative general election, due to the delivery of KPU logistics materials and party logistics, especially to the Eastern regions by air. This is a positive influence on political conditions.

5) Technology $\rightarrow$ Technology is an important thing for companies to pay attention to because every new technology and its innovations can affect the company's performance.

6) Competition $\rightarrow$ Competition is one factor that needs to be considered considering that there are currently so many shipping service companies emerging and with low rates. Important competitor analysis to be done to determine the performance of competitiveness, management must be able to develop research and development to increase market share and sales turnover. The Company's efforts in facing competition are effective communication with customers, increasing market share, competitive prices, improving the service quality.

2. Internal-External Analysis (IE Matrix)

This analysis is to identify external and internal factors. Before compiling the IE matrix analysis, first identify external factors, namely using the EFAS table, and identify internal factors in the IFAS table.

Table 1.EFAS Table

\begin{tabular}{|l|c|c|c|}
\hline \multicolumn{1}{|c|}{ External Strategy Factors } & Weight & Rating & $\begin{array}{c}\text { Weight X } \\
\text { Rating }\end{array}$ \\
\hline OPPORTUNITY: & 0,20 & 4 & 0,8 \\
1. High customer demand with the eastern route & & & \\
2. Effective communication with good customers & 0,10 & 3 & 0,3 \\
3. The growth of new industries & 0,05 & 3 & 0,15 \\
4. There is a high level of community activity & 0,15 & 1 & 0,15 \\
\hline THREAT: & & & \\
1. The creation of unhealthy competition between shipping & 0,20 & 3 & 0,6 \\
services & 0.10 & 4 & 0,4 \\
2. Uncertainty in market conditions & 0,05 & 3 & 0,15 \\
3. The emergence of a new delivery service & 0,15 & 2 & 0,3 \\
4. Very competitive price rates & & & \\
\hline
\end{tabular}

$\underline{\text { http://ijstm.inarah.co.id }}$ 


\begin{tabular}{|c|c|c|c|}
\hline TOTAL & 1,00 & 23 & 2,85 \\
\hline
\end{tabular}

Primary and secondary data

From the results of the analysis of the company's opportunities and threats, it can be seen with a total weight of 1.00 then multiplied by the rating to produce a value of 2.8 this value shows the company reacts to external strategic factors. Judging from the total score of 2.85 , it means that the company is in a middle position because if it is entered in the IE Matrix, it is in an intermediate position.

Table 2.IFAS Table

\begin{tabular}{|c|c|c|c|}
\hline External Strategy Factors & Weight & Rating & $\begin{array}{c}\text { Weight X } \\
\text { Rating }\end{array}$ \\
\hline $\begin{array}{l}\text { POWER: } \\
\text { 1. Privately-owned shipping company } \\
\text { 2. Has several agents and sub-agents } \\
\text { 3. Good distribution channels and information systems } \\
\text { 4. Marketing systems with pattern business to business, } \\
\text { although the system business to customer also carried }\end{array}$ & $\begin{array}{l}0.20 \\
0,10 \\
0,05 \\
0,15\end{array}$ & $\begin{array}{l}4 \\
4 \\
1 \\
4\end{array}$ & $\begin{array}{l}0,8 \\
0,4 \\
0,05 \\
0,6\end{array}$ \\
\hline $\begin{array}{l}\text { WEAKNESS: } \\
\text { 1. Promotional activities, especially the spread of flayer, } \\
\text { banners have not been continuously carried out so that the } \\
\text { product is not so well known by customers } \\
\text { 2. Sea transmission frequency is minimal } \\
\text { 3. Financial condition support is not so good }\end{array}$ & $\begin{array}{l}0,05 \\
0,20\end{array}$ & $\begin{array}{l}2 \\
2\end{array}$ & $\begin{array}{l}0,1 \\
0,4\end{array}$ \\
\hline TOTAL & 1,00 & 20 & 2,95 \\
\hline
\end{tabular}

Primary and Secondary Data

Based on the analysis of the strengths and weaknesses of the company, it can be seen that the total weight is 1.00 while the results of the weight multiplied by the rating produce a total score of 2.95 this total value shows how the company reacts to internal strategic factors. Judging from the total score of 2.95, the company is in the average position in the IE matrix.Determination of the company's position is based on an analysis of the total score of internal and external factors using the IE Matrix model which aims to obtain a more detailed overall business strategy at the corporate level.

Based on IE Matrix analysis can know the position of the company today that the Company is in a position through the growth period horizontal integration. In this position, the company can carry out the market expansion, facility improvement, or merger with other companies in the same industry. To achieve this growth the company differentiates shipping prices between industrial customers and individual customers to increase sales turnover. There is a tendency of competitors to conduct price competition to increase market share. The company also needs to improve the quality of service to attract new customers so that the company's revenue also increases.

\section{SWOT analysis}

Based on the identification of the company's internal-external factors, the company's strengths, weaknesses, opportunities, and threats can be identified the four variables, namely:

a. Strength (strengths)

1. Privately-owned shipping company

2. Have several agents and sub-agents

3. Good distribution channels and information systems

4. The marketing system with pattern business to business, though systems

business to customer executed as well.

b. Weaknesses (weakness)

1. Promotional activities, especially the spread of flayer, banners have not been continuously carried out so that the product is not so well known by customers

2. Sea transmission frequency is minimal

3. Financial condition support is not so good

c. Opportunity (opportunities) 
1. High customer demand with the eastern route

2. Effective communication with good customers

3. The growth of new industries

4. There is a high level of community activity

d. Threat (Threats)

1. The creation of unhealthy competition between shipping services

2. Uncertainty in market conditions

3. The emergence of a new delivery service

4. Very competitive price rates

\section{Strategy Formulation}

The strategy formulation is based on the results of the analysis that has been carried out on the company's external and internal environment with a SWOT analysis. In this regard, the company's strategies can be formulated, namely marketing strategies and strategies to increase the company's competitiveness (ST strategy).

a. Marketing strategy

b. strategy to increase the company's competitiveness

c. Competitive pricing policy strategy with competitors adjusted to market prices.

The Marketing Strategy Implications Business to Business On Delivery Services Company to Increase The Volume Of Delivery

Based on the SWOT analysis mentioned above, the company needs the right marketing strategy to increase sales turnover and be able to compete in the long term. The marketing strategy formulation business to business can be run in multiple applications of the following strategies:

a. Price (price)

Judging from the SWOT analysis, the company's price offer was very competitive, meaning that the price offered by the company is not too high based on the target of the market.

Companies applying special prices that give preferential prices to the business market by considering the number and range of delivery.

b. Product (product)

There needs to be product innovation in service products produced by the Company, service products must be supported by technology media that are currently developing to facilitate the production process because people's needs are oriented to things that are more practical, economical, safe, timeefficient. Therefore the product innovation offered by the company must consider all the needs and desires of the service as mentioned above.

c. Promotion (Promotion)

Promotion is important in the marketing strategy of the business to business company carries out promotional activities to introduce a service product innovation, such as: cooperation with the business world, especially the industries that their products of export-oriented, for example, the tobacco industry, textiles, crafts, industries shoes/slippers, and food and beverage, distribute stickers to agents or sub-agents to make popular the company, make cards member imposed on the consumer businesses.

d. Place (Place)

The Company's location is strategically close to industrial areas, so it is necessary to have location support facilities, the company's strategy is to complete physical and non-physical infrastructure and create a clean and comfortable location. This condition can affect and provide more value to the company so that it has an impact on the services offered

e. Distribution (Distribution)

In distributing its products, the Company uses agents or sub-agents.

\section{CONCLUSION}

Based on the identification of the problem and the results of the research that has been done, conclusions can be obtained as follows: 
1. The marketing strategy business to business run by the Company by applying a special rate (special price) to the business market where the special price, the price that has been set by the company's management. Furthermore, the company also communicates with customers, especially potential customers to increase the volume of shipments

2. With the implementation of marketing strategies business to business of the company can get great productivity and potential labor and time savings in the transaction, so that reduced costs.

\section{ACKNOWLEDGMENTS}

The author would like to thank everyone and society for their support and encouragement throughout the process until the completion of this research. It is hoped that it can be used as reading material to add insight and views of readers about business to business marketing strategies, as well as a source of reference and information for the same research size as well as a comparative study in the context of studying science.

\section{REFERENCE}

[1] Arikunto, Suharsimi, 2004. Research Procedure a Practical Approach, Jakarta: PT. Rineka Cipta

[2] Chandra, G. 2002. Marketing Strategy \& Program. Yogyakarta: Andi Offset

[3] Kotler. 1997. Marketing Management Analysis, Planning and Control. Volume 1. ter. Hendro Teguh. Jakarta: Eternal Independent Association.

[4] Kotler. 2005. Marketing Management vol 2: Issue 11. ter. Benjamin Molan. PT Intan Sejati Klaten. Jakarta.

[5] Handoko, Hani T. 2007. Personnel Management and Human Resources . Yogyakarta: BPFE

[6] Muslich, 2004, Islamic Business Ethics, Jakarta: Econisia

[7] Moleong, J Lexy. 2002. Qualitative Research Methods. Bandung PT. Rosdakarya Teens

[8] Rangkuti, Freedy. 2005. SWOT Analysis Techniques for Dissecting Business Cases, Jakarta: Gramedia Pustaka Utama

[9] _ 2002. SWOT Analysis Techniques for Dissecting Business Cases, vol.2, Jakarta: Gramedia Pustaka Utama

[10] Swastha, Basu. 1991. Principles of Marketing, Third Edition. Cetakan First Edition. Publisher Liberty Yogyakarta.

[11] Swastha, Basu and Irawan. 2003. Modern Marketing Management. YKPN. Yogyakarta 